\title{
EVALUATION OF ACCURACY AND REPRODUCIBILITY OF THE OPTICAL MEASURING SYSTEM IN CAST MACHINE TOOL BODY ASSESSMENT
}

\author{
Andrzej Gessner, Roman Staniek
}

\begin{abstract}
S u m m a r y
The hereby presented study puts forth the fundamentals of an innovative technology enabling rapid assessment of machine tool cast shape by elimination of manual marking out requirement and machining surplus minimization. The new technique is based on optical measuring system utilization for the design of virtual cast models and their comparative analysis with structural models. Two small scale machine tool body casts were selected for the investigation. The measurements were conducted in triplicate series for each cast labeled with reference markers, by means of Atos GOM II optical scanner. For further comparison, one of the casts was additionally scanned without labeling. Flatness parameters of selected cast surfaces were determined for geometric accuracy evaluation and the scanned cast shapes were compared with reference models. The comparison results were recorded as multicolored maps projected upon the experimental cast and reference model surfaces. Practical map interpretation was further elucidated and the surplus sizes on the machined surfaces were assessed accordingly. Comparative analyses of individual models were demonstrated for all measurement series of both casts, affording reproducibility evaluation of optical scanning system measurements. Economic viability of the proposed technology market implementation was unequivocally established, as it provides for considerable reduction in the cast machining scale as well as the quality control of $100 \%$.
\end{abstract}

Keywords: marking out, cast body, evaluation of cast

Ocena powtarzalności pomiarów za pomocą systemu optycznego korpusów odlewanych

Streszczenie

W pracy przedstawiono założenia nowej metody szybkiej oceny kształtu odlewów. Eliminuje ręczne trasowanie odlewów oraz minimalizuje naddatki obróbkowe. Podstawą metody jest zastosowanie optycznego systemu pomiarowego do tworzenia wirtualnych modeli odlewów oraz analizy porównawczej z modelami konstrukcyjnymi. Przyjęto do badań 2 rodzaje odlewów korpusowych o małych rozmiarach - komponentów obrabiarek skrawających. Pomiary prowadzono za pomocą skanera optycznego Atos GOM II. Wykonano serię 3 pomiarów każdego odlewu oklejonego znacznikami referencyjnymi. Dodatkowo, w celach porównawczych, jeden z odlewów zeskanowano bez znaczników. Dla oceny dokładności geometrycznej odlewów określono parametr płaskości dla wybranych ich powierzchni. Porównano kształt odlewów z modelami referencyjnymi. Wyniki badań przedstawiono w postaci map naniesionych na powierzchnie odlewu oraz modelu referencyjnego. Dokonano ich praktycznej interpretacji oraz oceny wielkości naddatków na powierzchniach obrabianych. Dla wykonanych serii pomiarów obu odlewów przedstawiono porównanie wyników poszczególnych modeli. Stanowiło to podstawę oceny powtarzalności pomiarów za pomocą optycznego systemu skanującego. Dokonano oceny efektów ekonomicznych opracowanej metody pomiarów. Słowa kluczowe: trasowanie, odlew korpusowy, ocena odlewu

Address: Andrzej GESSNER, Ph.D. Eng., Roman STANIEK, D.Sc. Eng. Prof., Institute of Mechanical Technology, Poznan University of Technology, Poland, e-mail: andrzej.gessner@put.poznan.pl 


\section{Introduction}

Marking out is one of the initial technological procedures in modern production processes utilizing cast elements. It allows assessment of cast allowances accuracy through drawing allowances defining gouges on the cast raw surfaces. Marking out is a manual operation and, depending on size and complexity, might take up to several working shifts for prototype casting.

Herein, we introduce an innovative technology applying a contactless optical measuring system and eliminating the necessity of manual marking out. The aim of this new technological approach is to afford rapid machine tool cast shape verification as well as optimal machining coordinate system center determination, according to the defined accuracy requirements. The fundamentals of the method were explicated previously. Moreover, the means of spatial cast model design according to the acquired optical scanning data, followed by a comparative analysis of the virtual model with a reference standard - a 3D model of the defined machine tool body designed after machining, were proposed $[1,2]$. We further postulated that the scanning data thus obtained be a basis for optimized planning of cast machining, resulting in allowances minimization [3, 4]. Initial experimental trials unequivocally confirmed the theoretical premises and prospective practical applicability of our new technological solution [5].

State-of-the-art literature fails to provide conclusive information concerning the accuracy and reproducibility of optical scanning measurement for cast surfaces, while the technical specifications of such measuring systems supply accuracy data relevant merely for a defined area of measurement. To address this issue, we initiated investigation aimed specifically at scanning accuracy and reproducibility determination for machine tool body casts. Two small scale $(5-15 \mathrm{~kg})$ casts were selected as measurement models.

\section{Initial investigation}

A bumper bracket $(8 \mathrm{~kg})$ and a bed-frame bracket $(16 \mathrm{~kg})$ were the selected model small scale machine tool casts (Fig. 1).

Series of 3 measurements were conducted for each cast. The model casts were placed on a rotary table, with distance pads separating the table surface and the cast, which aided the measuring process by setting the geometry of the scanned surfaces apart from that of redundant layers (e.g. the table plane). The measured elements were labeled with reference markers (Fig. 2a). Since the scanned casts approximately fit within the area of measurement of the Atos GOM II scanner, the tests were conducted without the use of Tritop HR photogrammetric system - indispensable for accurate determination of reference marker inter-localization while measuring larger objects, enabling precise 
adjustment of consecutively scanned surfaces. For further comparison, the bumper bracket cast was additionally measured without labeling.

The number of essential scanning transitions was determined depending on the size of the measuring area as well as the detection range of the utilized camera system (Fig. 2b). To obtain the full surface geometry definition, the casts were rotated during measurement. The correct inter-adjustment of consecutively scanned areas was dependent on the presence of at least 3 reference markers on the surface geometry measured previously, and 3 markers on the currently scanned surface geometry.

a)

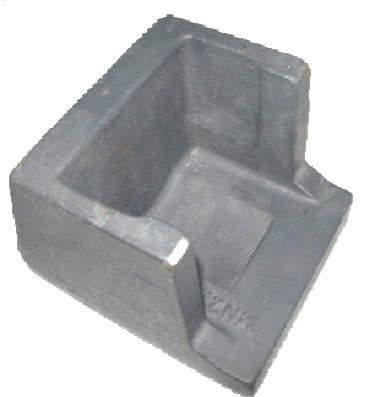

b)

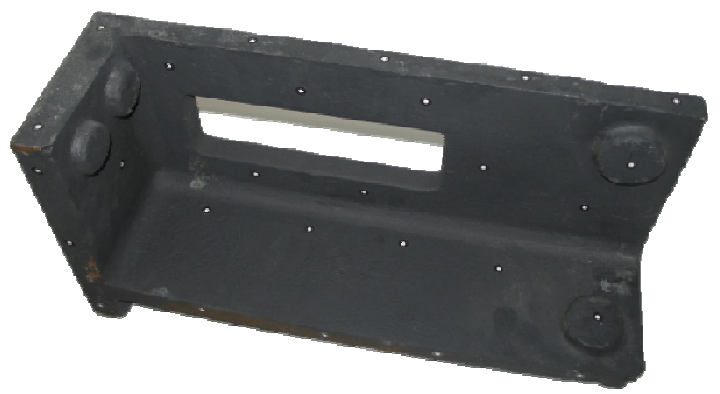

Fig. 1. Scanned casts: a) bumper bracket, b) bed-frame bracket

a)

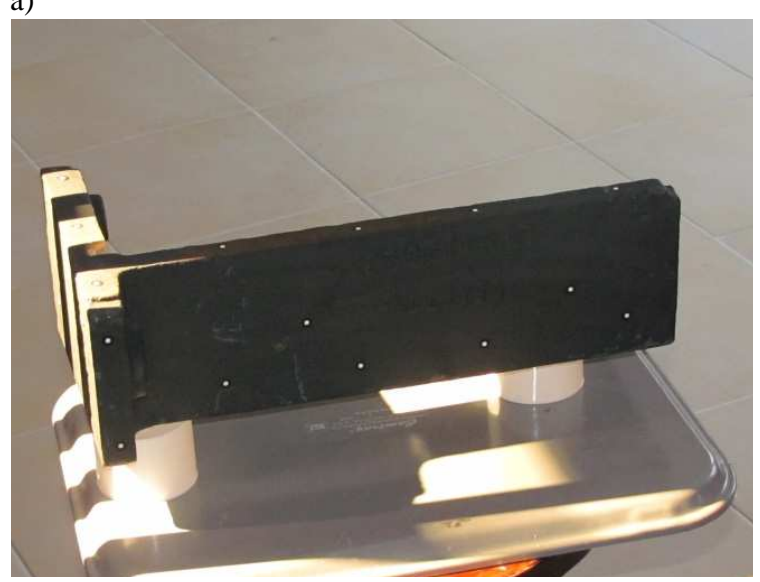

b)

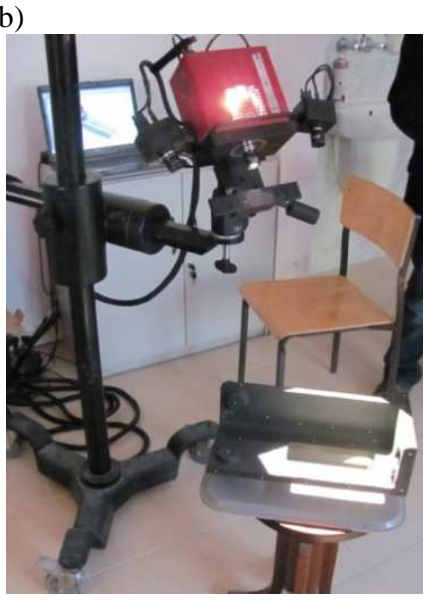

Fig. 2. Cast labeled with reference markers (a), optical scanning system Atos GOM II during measurement (b)

The conducted measurements resulted in a series of spatial models of both casts, while the scanner software enabled further comparison of individual models with each other and with the reference models - casts designed in CAD system after machining. 


\section{Measurement results and cast assessment}

Firstly, basing on the measurement results, initial assessment of cast quality was conducted through determination of the flatness parameter for selected surfaces. The scanner software, by analyzing the area around a defined measuring point, denoted the scanned surface according to the assigned criteria, the software-specific algorithm, and the 2 available methods of plane-to-surface adjustment of Gauss and Czebyszew.

Examples of outcomes obtained for both casts are depicted in Fig. 3, showing surface quality consistent with the quality control requirements and affording straightforward, unproblematic machining.

a)

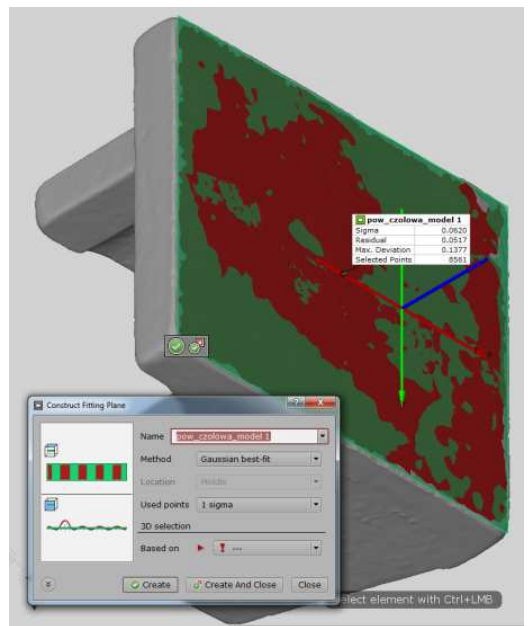

c)

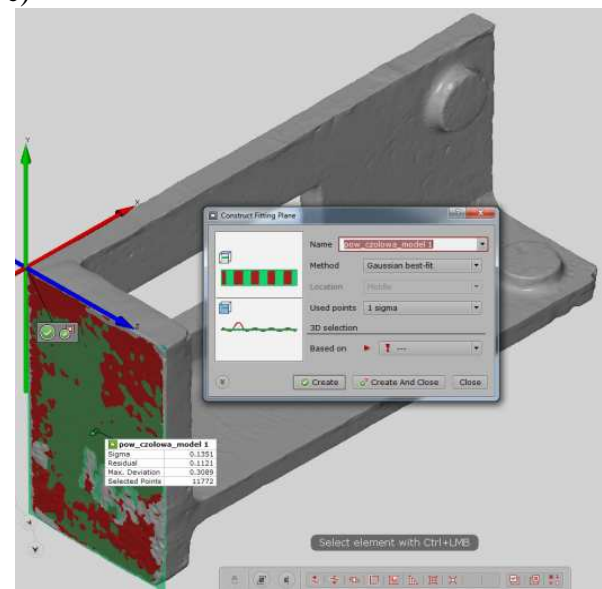

b)

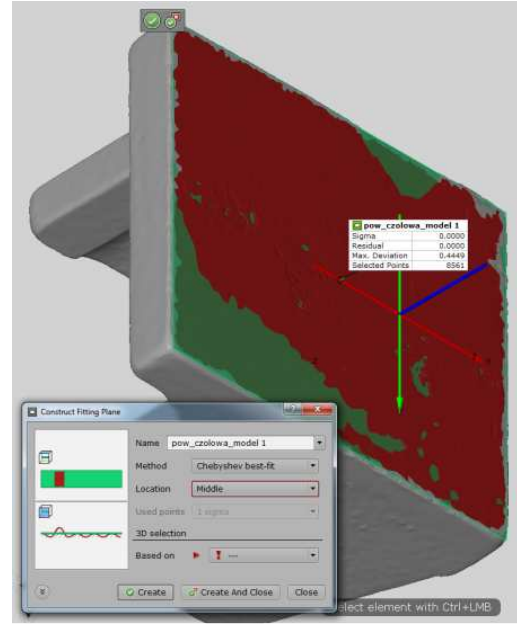

d)

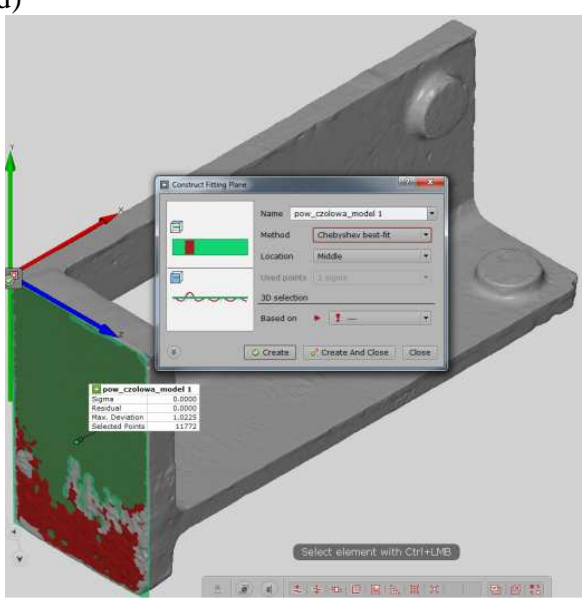

Fig. 3. Assessment of flatness of the machined surfaces: a, b) bumper bracket cast, c, d) bed-frame bracket cast (a, c adjustment according to Gauss; b, d adjustment according to Czebyszew) 
Furthermore, the shape of the investigated casts was assessed through comparative analysis of the scanned models with reference standards - model casts designed in CAD 3D system after machining. Shape evaluation requires appropriate relative orientation of the scanned cast and the reference model. From among several software-specific methods, the bestfit technique was selected for both models - providing for the optimal adjustment of the scanned surface geometry to the source standard, resulting in a minimal sum of normal distances, as measured in reference points, between all investigated surfaces [6].

a)

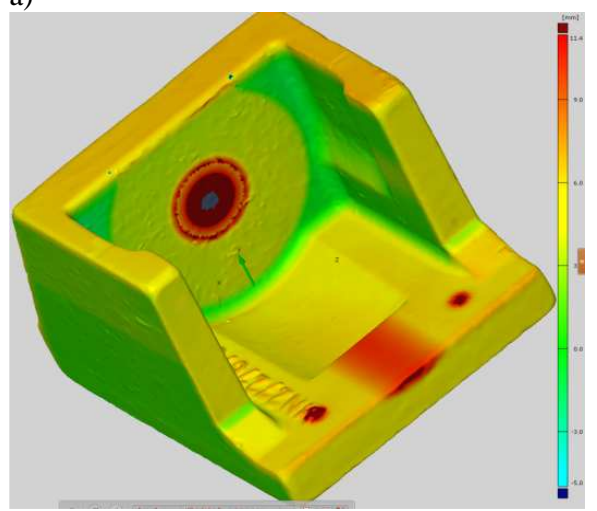

b)

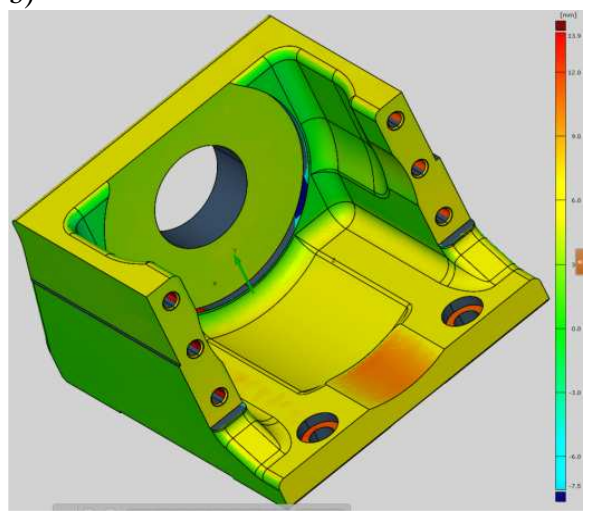

c)

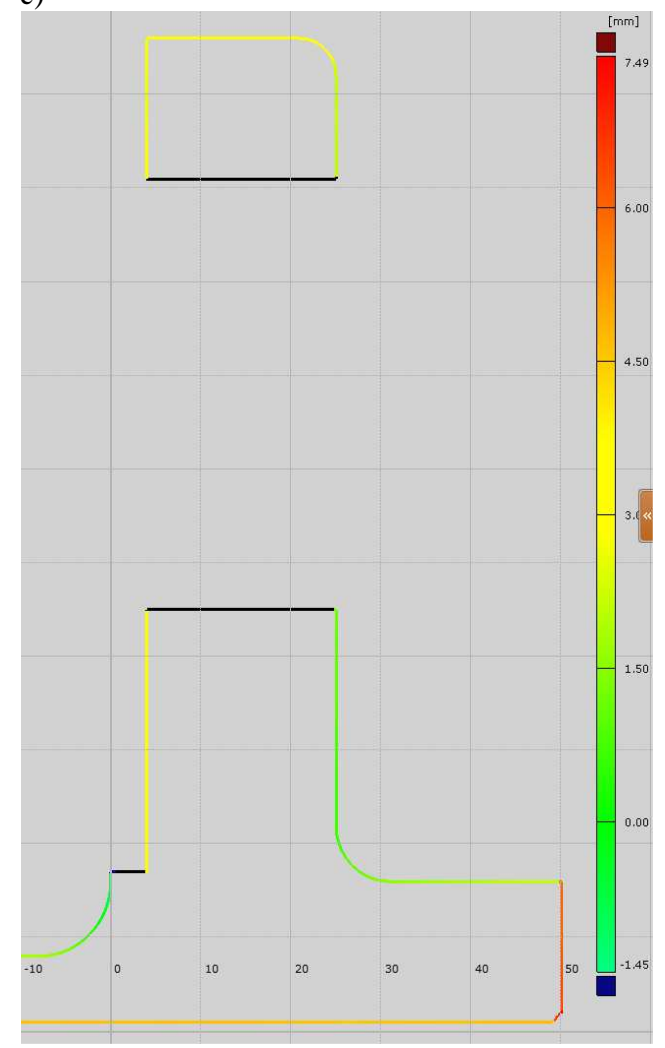

Fig. 4. Comparison of the scanned model shape with that of the reference model: a) on the cast surface, $b$ ) on the reference model surface, c) in longitudinal cast cross-section

The comparison results were recorded as multicolored maps projected upon the experimental cast and reference model surfaces. Individual colors denote inter-model distances in the given reference points. Green corresponds to full compatibility (distance near zero). Light- to dark-blue indicates negative distance values, which may be interpreted as casting faults due to lack of 
material. Yellow merging into red designates positive distance values, corresponding to the machining surplus sizes of the investigated surfaces. To increase the analysis accuracy, the comparison may be illustrated in any crosssection of the cast. Fig. 4 shows an exemplary comparative juxtaposition between the investigated cast and the reference model.

The comparison results recorded as 3D models featuring multicolored maps illustrating the accuracy of casting enable the technologists to quickly assess the adequacy of surpluses on all machined surfaces (yellow merging into red). Such evaluation constitutes the first step to ultimate elimination of the cumbersome manual cast marking out procedure from the technological process.
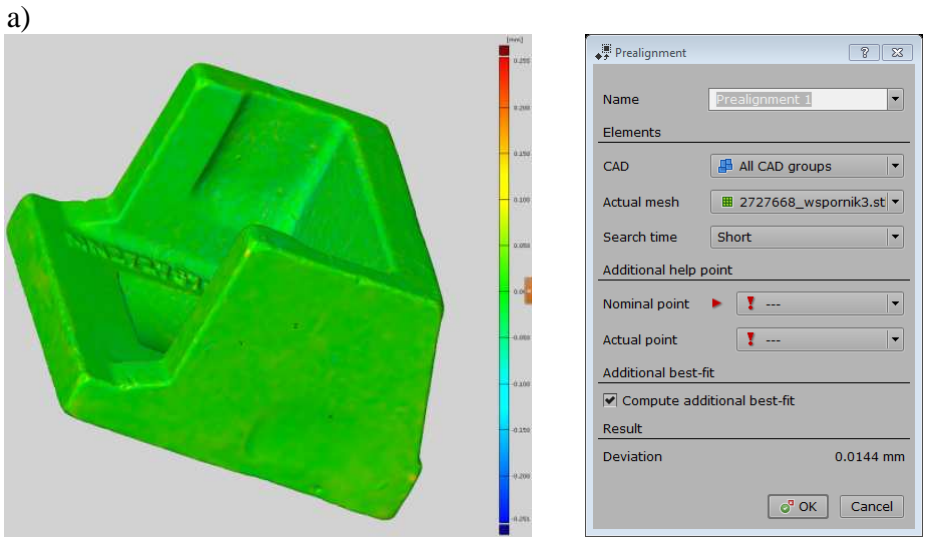

b)
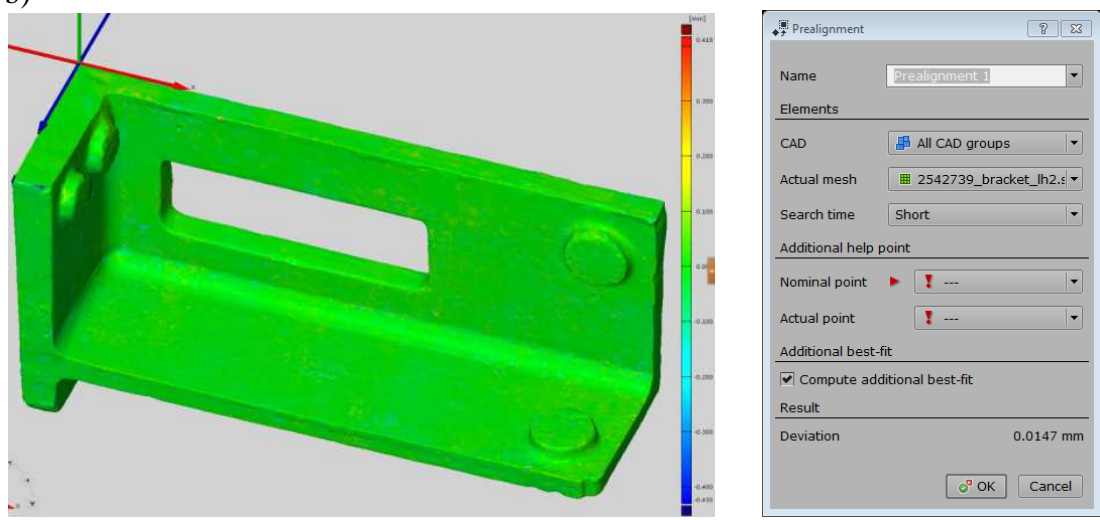

Fig. 5. Comparison of models obtained from 2 consecutive measurements: a) bumper bracket cast, b) bed-frame bracket cast

Since the optical measuring system producers (e.g. GOM GmbH) do not specify the measurement accuracy and reproducibility, but merely give the number of (or the distance between) measurement points corresponding to 
a defined area, initial investigation of the reproducibility of measurement was undertaken for the selected casts.

Figure 5 depicts graphical comparison results of 2 consecutive measurements for both investigated casts. The maximal software-recorded deviations ranged up to several hundredths of a mm.

Table 1 illustrates the comparative juxtaposition of cast models obtained from consecutive measurements. The models were adjusted by means of bestfit method of the Atos GOM II software, accounting for all scanned surfaces. The Deviation parameter designates the maximal normal distance between the surfaces of inter-matched models. The obtained outcome deviations, not exceeding $0.15 \mathrm{~mm}$ (for the smaller cast) and $0.25 \mathrm{~mm}$ (for the larger cast), facilitate the prospective outlook on the attainable reproducibility of the optical scanning system measurements. Thus achieved measurement reproducibility is perfectly sufficient for cast quality assessment, as well as for further development of the contactless cast marking out technology and machining surplus minimization.

Table 1. Comparison of models obtained from consecutive measurements (max normal distance: mm, after bestfit adjustment)

\begin{tabular}{|c|c|c|c|}
\hline \multicolumn{4}{|c|}{ Bumper bracket } \\
\hline $\begin{array}{c}\text { Deviation, } \\
\text { mm }\end{array}$ & $\begin{array}{c}\text { Measurement } \\
1\end{array}$ & $\begin{array}{c}\text { Measurement } \\
2\end{array}$ & $\begin{array}{c}\text { Measurement 4 } \\
\text { (no labeling) }\end{array}$ \\
\hline $\begin{array}{c}\text { Measurement } \\
1\end{array}$ & & & 0,0215 \\
\hline $\begin{array}{c}\text { Measurement } \\
2\end{array}$ & 0,0131 & 0,0231 \\
\hline $\begin{array}{c}\text { Measurement } \\
3\end{array}$ & 0,0144 & 0,0136 & 0,0201 \\
\hline \multicolumn{3}{|c|}{ Bed-frame bracket } \\
\hline $\begin{array}{c}\text { Deviation, } \\
\text { mm }\end{array}$ & $\begin{array}{c}\text { Measurement } \\
1\end{array}$ & $\begin{array}{c}\text { Measurement } \\
2\end{array}$ & $\begin{array}{c}\text { Measurement 4 } \\
\text { (no labeling) }\end{array}$ \\
\hline $\begin{array}{c}\text { Measurement } \\
1\end{array}$ & \multicolumn{3}{c|}{} \\
\hline $\begin{array}{c}\text { Measurement } \\
2\end{array}$ & 0,0147 & 0,0195 & \\
\hline $\begin{array}{c}\text { measurement } \\
3\end{array}$ & 0,0237 & & \\
\hline
\end{tabular}

\section{Summary}

The hereby presented report demonstrates the fundamentals of an innovative technology enabling rapid and full control of machine tool casting geometric accuracy, by means of contactless optical measuring system. The 
direct advantage of the prospective implementation of the investigated technological solution is the ultimate elimination of the arduous manual cast marking out procedure from the production process. We further postulate that this new technology will facilitate the decrease in machining scale through surplus minimization, as it was estimated that the cuts in machining surplus could reach up to $15-30 \%$, ultimately resulting in chips reduction of around $1.5-6.0 \%$ of the total casting mass [1]. Thus, a firm producing up to 2400 medium-size machine tools a year (cast iron demand of around 10000 tons) would generate from 150 to 600 tons of chips less. This entails further reduction of machine tool and cutting device overexploitation, the latter being of considerable economic importance. What is more, the introduction of the postulated casting control quality of $100 \%$ will help avoid unnecessary and costly interruptions in production due to faulty cast detection.

\section{Acknowledgments}

The proposed technique has been elaborated within the ongoing project No. 0909/R/T02/2010/10.

\section{References}

[1] K. MROZEK, A. GESSNER: Optymalizacja naddatków obróbkowych wielkogabarytowych odlewów żeliwnych. Postępy Nauki i Techniki, Lublin 2011.

[2] A. GESSNER, R. STANIEK, K. MROZEK: Metoda przygotowania odlewu do obróbki i optymalizacji warstwy skrawanej. 50 Sympozjon „Modelowanie w mechanice", Wisła 2011.

[3] A. GESSNER: Zgłoszenie patentowe nr P-390364 z dnia 5.02.2010, Sposób przygotowania odlewu do obróbki.

[4] A. GESSNER: Zgłoszenie patentowe nr P-390852 z dnia 31.03.2010, Sposób przygotowania odlewu do obróbki z minimalizacją naddatków.

[5] A. GESSNER: Ocena dokładności wykonania odlewu i minimalizacja naddatków na obróbkę w korpusach obrabiarek. Przeglad Mechaniczny, (2012)3.

[6] Atos GOM II technical specifications, www.gom.com. 